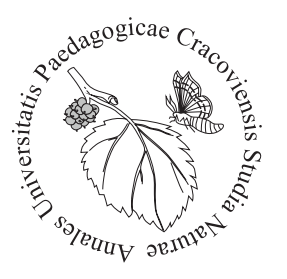

Arkadiusz Gruca

Institute of Biology, Faculty of Geography and Biology, Pedagogical University of Cracow, Cracow, Poland, Arkadiusz.gruca@up.krakow.pl

\title{
A brief review of microbial induced corrosion research
}

Corrosion is a natural process of the gradual conversion of refined materials, such as metal or concrete, into a more chemically stable form, e.g., sulphide, nitrate, or oxide. Corrosion closely corresponds with destruction of materials exposed to the environment (Schweitzer, 2010).

Some microorganisms possess the ability to accelerate corrosion. This process is called Microbial Induced Corrosion (MIC). MIC is associated with formation of bacterial biofilms. Biofilm is a bacterial community embedded in extracellular matrix formed by EPS (extracellular polymeric substances) secreted by bacteria. Products of bacterial metabolism are very corrosive to metal and concrete surfaces that the biofilm is attached to, and so microbial induced corrosion is a significant threat to metal and concrete surfaces (Javed et al., 2015). Pipelines, fuel tanks, ship hulls, sewage systems, and other elements exposed to freshwater, seawater, sewage, or soil are especially susceptible to MIC (Cayford et al., 2017; Hunsucker et al., 2018; Grengg et al., 2018). Repairing damage caused by bacteria costs billions of dollars a year (Koch et al., 2002).

Scientists recognise the threat posed by microorganisms and are conducting extensive research. Mine study goals are the identification of bacterial communities responsible for accelerated corrosion of materials, the explanation of the main microbial induced corrosion mechanisms and effective inhibitors of this kind of corrosion, and the creation of MIC resistant materials.

The aim of this study is review the latest advances in Microbial Induced Corrosion research, compare currently used biocorrosion prevention methods, and to discuss chemical and biological processes behind microbial induced corrosion.

Corrosion inducing bacteria

Corrosion is induced by wide range of bacteria. The most prevalent of over 13 phyla related to biocorrosion in various environments are Bacterioidetes Krieg et al. 2012, 
Proteobacteria Stackebrandt et al., 1988 and Firmicutes Gibbons \& Murray 1978 (Cayford et al., 2017; Li et al., 2017a; Hunsucker et al., 2018; Li et al., 2018). Overall, more than 20 classes of bacteria were proven to induce corrosion (Li et al., 2017), the most abundant of them being Deltaproteobacteria Stackebrandt et al. 1988, Clostridia Rainey 2010 and Gammaproteobacteria Stackebrandt et al. 1988 (Cayford et al., 2017; Li et al., 2017a; Hunsucker et al., 2018). On the genera level, the most common MIC causing bacteria are Desulfovibrio Kluyver \& van Niel 1936, Desulfobacter Widdel 1981 and Desulfotomaculum Campbell \& Postgate 1965, all three belonging to Sulphate Reducing Bacteria (SRB) group (Hamilton, 1985; Jia et al., 2017; Wan et al., 2018).

Sulphate reducing bacteria are considered to be the typical MIC causing microorganisms, thanks to their ability to accelerate corrosion in anaerobic environments (Videla, 1986; Sherar et al., 2011; Dec et al., 2016). Studies have shown that SRB, apart from corrosion acceleration, can also lead to corrosion inhibition. Sulphides created by bacteria can form films on the surface. Thin films work as corrosion inhibitors, while more bulky films can accelerate the corrosion rate (Videla et al., 2005; Xu et al., 2013). As SRBs are strictly anaerobic, most of the research regarding corrosion effects of SRBs is focused around anaerobic environments.

In recent years, another group of corrosion inducing bacteria has gained a lot of researchers' attention, that group being Nitrate Reducing Bacteria (NRB). NRBs have proven to induce corrosion include gene Bacillus Cohn 1872, Acidithiobacillus Kelly \& Wood 2000 and Alcaligenes Castellani \& Chalmers 1919, (Wang et al., 2014; Liu et al., 2016; Herisson et al., 2017). Studies have shown that corrosion caused by NRBs can be more serious that that caused by SRBs (Wan et al., 2018). Despite the intensive research, corrosion the mechanism of NRB still needs more investigation.

\section{MIC as a topic of scientific research}

In recent years, microbial induced corrosion has been gaining more and more attention among scientists from a range of scientific fields. Due to the material destructing nature of MIC, most of the research revolves around the development of corrosion resistant materials, corrosion inhibitors, and the recognition of MIC mechanisms.

MIC has been proven as one of the main factors in concrete degradation. Corrosion of wastewater networks poses a high risk to the environment and public health (World Health Organisation, 2000; Li et al., 2017b). The range of Volatile Organic Compounds (VOCs) produced as bacterial metabolites constitute considerable health and safety issues for sewage systems operators and community workers (Alexander et al., 2013; Gutierrez et al., 2014). Despite intensive in situ and lab research, corrosion resistant concrete is still not available for wide usage. Not one of the currently 
used concrete mixtures can resist MIC for their projected operating lifetime (Goyns, Alexander, 2014; Herisson et al., 2014). Experience has shown that physiochemical concrete parameters are very important for MIC resistance (Vincke et al., 2002; Herisson et al., 2014). Mixtures with high bacterial created acid neutralisation capacity and small pores were proven to be especially resistant to corrosion (Gu et al., 2011; Li et al., $2017 \mathrm{~b}$ ). Antibacterial additives, such as $\mathrm{ZnO}$ powder, were also proven to be effective in slowing down MIC (Schultz et al., 2011).

Water transportation is another field in which MIC causes considerable loses every year. Ship hulls, and fuel and ballast tanks are especially endangered. Seawater is a perfect environment for bacteria, thanks to abundance of organic and mineral compounds necessary for bacteria to thrive, and a relatively stable temperature. Intercontinental water transport highly contributes to the propagation of bacteria around the globe (Souza et al., 2016).

The accumulation of bacterial biofilm, responsible for corrosion on ship hulls causes increased drag, which leads to higher fuel consumption and increased exhaust emissions (Swain, 2010). To negate this problem, biocides and anti-adhesion coatings are used (Lee et al., 2012). Because of high toxicity of biocides, new methods of protecting ship hulls are being developed. One of the new methods that show promise is grooming (Hunsucker et al., 2018). Grooming is based on brushing the surface attacked by bacteria and removing biofilms, and other contaminations. The groomed surface is smoother and thereby more resistant to bacterial adhesion. However, more research is required to refine grooming tools and procedures.

Studies have shown that biodiesel fuels can accelerate the corrosion of carbon steel fuel tanks in contact with marine microbes (Bellige et al., 2015). Cu-Ni coatings used for protection of fuel tanks against corrosion were proven to be not effective against MIC. Bacterial sulphate reduction corresponding with fuel biodegradation can lead to rapid penetration of the protecting coating and the corrosion of external steel layers (Lv et al., 2017). Latest research shows that the type of fuel is a major factor in $\mathrm{Cu}-\mathrm{Ni}$ coating corrosion (Hunsucker et al., 2018). To fight this, new generations of biofuels are being implemented (Liang et al., 2017).

The environment of the oral cavity is a perfect incubator for bacteria (Long, Rack, 1998). Because of that, large emphasis is given for development of MIC resistant dental implants. The most widely used material for implant production is titanium, known for its biocompatibility and corrosion resistance (Navarro et al., 2008; Diaz et al., 2018). The corrosion resistance of titanium comes from its ability to passivate and create a 2-5 $\mathrm{nm}$ thick protective oxide layer on the implant surface. However, recent studies have shown that bacteria can accelerate titanium corrosion in the oral cavity environment (Li et al., 2017). Roughness of the implant surface also plays a major role in MIC resistance, and because of that, a range of surface modifications are being 
extensively tested (Souza et al., 2016). The goal is to achieve high corrosion resistance without lowering biocompatibility of the implant.

\section{MIC prevention methods}

Because of high maintenance costs of elements affected by MIC, a lot of emphasis is given to the development of effective anti-corrosion agents, coatings, and corrosion resistant materials. The application of biocides, such as bronopol and innovative coatings containing antibacterial nanoparticles are being tested.

Bronopol (2-bromo 2-nitropropane-1.3-diol) is a well-known anti-microbial agent. It can form a protective layer on the surface of metal, thus protecting it against bacteria. Studies have shown that bronopol can considerably reduce the corrosion rate of mild steel (Narenkumar et al., 2018). However, according to Sharma et al. (2017), high concentrations of bronopol can lead to an increase in the corrosion rate. Because of that, high dosages of bronopol should be avoided.

The use of bioengineered silver nanoparticles (NPs) is an innovative method of preventing MIC (Narenkumar et al., 2018). Thanks to their high antibacterial potential, silver nanoparticles are very effective in stopping biofilm development (Sondi, Salopek-Sondi, 2004; Kim et al., 2007; Narenkumar et al., 2018). Analyses have shown that silver NPs can be absorbed by the metal surface and form a protective layer, which adds to their anticorrosive properties. Unfortunately, silver NPs have been proven as highly toxic and hazardous for the environment (Hajipour et al., 2012; Bondarenko et al., 2013; Yuan et al., 2017).

The usage of many anti MIC agents is very limited due to their high toxicity and destructing influence on the natural environment. Because of that, eco-friendly alternative solutions are being developed. One of them is the usage of plant-based natural corrosion inhibitors (Narenkumar et al., 2017; Punniyakotti et al., 2017). Many plants are well known for their antibacterial properties (Raja, Sethuraman, 2008; Narenkumar et al., 2017; Punniyakotti et al., 2017; Aribo et al., 2017), and can be used to prevent corrosion. Studies have shown that ginger (Zingiber officinale Rosc.) in concentrations as low as $20 \mathrm{ppm}$ inhibits MIC with over $80 \%$ efficiency (Narenkumar et al., 2017). Despite high potential of natural inhibitors, more research is required to develop effective ways of implementing them in in situ conditions.

MIC mechanisms

Anaerobic bacterial metabolism can be divided into two types: fermentation and respiration (Błaszczyk, 2010). With that classification, anaerobic microbial induced corrosion can be divided into three main categories (Xu, Gu, 2011; Gu, 2012; Xu et al., 2013). 
In standard conditions, organic carbon is a main source of nourishment for microbes. Bacteria subjected to carbon starvation have been shown to accelerate carbon steel corrosion. With the lack of carbon, bacteria were using metallic iron as a source of electrons needed for the oxidation process (Jia et al., 2017). Metals that can be used as electron donors are more susceptible to biocorrosion (Xu et al., 2016). In MIC I, extracellular electrons realised in oxidation of iron are used by bacteria to reduce oxidants such as sulphate or nitrate in their cytoplasm. For this to happen, electrons must be transported through a cell wall, this is called extracellular electron transfer (EET). Two main methods of EET are used by bacteria: mediated electron transfer (MET) and direct electron transfer (DET). The addition of electron mediator into Desulfovibrio vulgaris (Hildenbor) culture medium accelerated corrosion (Zhang et al., 2015). This shows that electron transfer is a limiting factor in MIC. A theory called Biocatalytic Cathodic Sulphate Reduction (BCSR) was proposed to describe the thermodynamics of microbial induced corrosion caused by SRB (Gu et al., 2009). In this theory, sulphate is the terminal electron acceptor, and iron oxidation occurs extracellulary, and sulphate reduction occurs in the SRB cytoplasm. BCSR can be used as a base for computer modelling of MIC caused by sulphate reducing bacteria. Various factors (i.e., temperature, biofilm aggressiveness, $\mathrm{pH},\left[\mathrm{SO}_{4}^{2-}\right]$ ) influencing corrosion speed can be investigated through computer simulation (Xu et al., 2016).

Biocatalytic Cathodic Nitrate Reduction (BCNR) is a theory parallel to BCSR, and it can explain MIC caused by nitrate reducing bacteria. Nitrate reduction associated with extracellular iron oxidation can cause corrosion more severe than that linked to sulphate reduction ( $\mathrm{Gu}, 2012$; $\mathrm{Xu}$ et al., 2016).

MIC II is caused by corrosive bacterial metabolites (i.e., organic acids and sulphides) released into biofilm. In this type of MIC, metabolites are used by bacteria to achieve redox balance (Shuler, Kargi, 2002). The $\mathrm{pH}$ difference between biofilm and surrounding liquid leads to the acidic corrosion of surface underneath the biofilm (Xu et al., 2016). It is still unknown if this process is deliberate and if bacteria secrete corrosive metabolites for the purpose of harvesting energy (Li et al., 2018).

Type III MIC can be best described as the biodegradation of organic materials caused by microbes. In humid environments, microorganisms, such as fungi, excrete enzymes that digest organic matter transforming it into substances that can be absorbed into cells. This kind of microbial induced corrosion can damage polymer insulations and lead to the failure of electrical systems ( $\mathrm{Gu}, 2003)$.

\section{Conclusions}

The state of the art knowledge of microbial induced corrosion was reviewed in this study. Despite major advances in recent years, more research is still required to accu- 
rate the description of MIC process in nature and the development of more effective biocorrosion inhibitors. Computer simulation can help accelerate research speed and largely contribute towards new discoveries in MIC studies. Better understanding of MIC mechanisms allowed for the development of corrosion resistant materials and new ways of fighting corrosive microbes. Scientists are on the right path, and rapid progress in microbial induced corrosion research is becoming more and more apparent.

\section{References}

Alexander, M., Bertron, A., De Belie, N. (2013). Performance of cement-based materials in aggressive aqueous environments. 1st ed. Ghent: Springer. DOI: 10.1007/978-94-007-5413-3

Aribo, S., Olusegun, S.J., Ibhadiyi, L.J., Oyetunji, A., Folorunso, D.O. (2017). Green inhibitors for corrosion protection in acidizing oilfield environment. Journal of the Association of Arab Universities for Basic and Applied Sciences, 24, 34-38. DOI: 10.1016/j.jaubas.2016.08.001

Bellige, S., Elias, L., Hegde, A.C (2015). Electrodeposition of Cu-Ni coatings for marine protection of mild steel. Innovations in Corrosion and Materials Science, 5(2), 127-131. DOI: 10.2174/235209490 502151106195950

Błaszczyk, M.K. (2010). Mikrobiologia środowisk. Warszawa: PWN. [In Polish]

Bondarenko, O., Juganson, K., Ivask, A., Kasemets, K., Mortimer, M., Kahru, A. (2013). Toxicity of Ag, $\mathrm{CuO}$ and $\mathrm{ZnO}$ nanoparticles to selected environmentally relevant test organisms and mammalian cells in vitro: a critical review. Archives of Toxicology, 87(7), 1181-1200. DOI: 10.1007/s00204-013-1079-4

Cayford, B.I., Jiang, G., Keller, J., Tyson, G., Bond, P.L. (2017). Comparison of microbial communities across sections of a corroding sewer pipe and the effects of wastewater flooding. Biofouling, 33(9), 780-792. DOI: 10.1080/08927014.2017.1369050

Dec, W., Mosiałek, M., Socha, R.P., Jaworska-Kik, M., Simka, W., Michalska, J. (2016). The effect of sulphate-reducing bacteria biofilm on passivity and development of pitting on 2205 duplex stainless steel. Electrochimica Acta, 212, 225-236. DOI: 10.1016/j.electacta.2016.07.043

Diaz, I., Pacha-Olivenza, M.Á., Tejero, R., Aniuta, E., González-Martín, M.L., Escudero, M.L., Garcia-Alonso, M.C. (2018). Corrosion behavior of surface modifications on titanium dental implant. In situ bacteria monitoring by electrochemical techniques. Journal of Biomedical Materials Research. Part B, Applied Biomaterials, 106(3), 997-1009. DOI: 10.1002/jbm.b.33906

Goyns, A.M., Alexander, M. (2014). Performance of various concretes in the Virginia experimental sewer over 20 years. Calcium Aluminates, Balkema, 573-584.

Grengg, C., Mittermayr, F., Ukrainczyk, N., Koraimann, G., Kienesberger, S., Dietzel, M. (2018). Advances in concrete materials for sewer systems affected by microbial induced concrete corrosion: A review. Water Research, 134(1), 341-352. DOI: 10.1016/j.watres.2018.01.043

$\mathrm{Gu}$, J.D. (2003). Microbiological deterioration and degradation of synthetic polymeric materials: recent research advances. International Biodeterioration \& Biodegradation, 52(2), 69-91. DOI: 10.1016/ S0964-8305(02)00177-4

Gu, J.D., Ford, T.E., Mitchellm, R. (2011). Microbiological corrosion of concrete. Uhlig's Corrosion Handbook, John Wiley \& Sons, 451-460.

$\mathrm{Gu}$, T. (2012). Can acid producing bacteria be responsible for very fast MIC pitting. Corrosion 2012, p. C2012-0001214, Salt Lake City: UT.

Gu, T., Zhao, K., Nešic, S. (2009). A practical mechanistic model for MIC based on a Biocatalytic Cathodic Sulfate Reduction (BCSR) theory. Corrosion 2009, p. 09390, Atlanta: GA. 
Gutierrez, O., Sudarjanto, G., Ren, G., Ganigué, R., Jiang, G., Yuan, Z. (2014). Assessment of pH shock as a method for controlling sulfide and methane formation in pressure main sewer systems. Water Research, 48, 569-578. DOI: 10.1016/j.watres.2013.10.021

Hajipour, M.J., Fromm, K.M., Ashkarran, A.A., Jimenez de Aberasturi, D., de Larramendi, I.R., Rojo, T., Serpooshan, V., Parak, W.J., Mahmoudi, M. (2012). Antibacterial properties of nanoparticles. Trends in Biotechnology, 30(10), 499-511. DOI: 10.1016/j.tibtech.2012.06.004

Hamilton, W.A. (1985). Sulphate-reducing bacteria and anaerobic corrosion. Annual Review of Microbiology, 39, 195-217. DOI: 10.1146/annurev.mi.39.100185.001211

Herisson, J., Gueguen-Minerbe, M., Van Hullebusch, E.D., Chaussadent, T. (2014). Biogenic corrosion mechanism: Study of parameters explaining calcium aluminate cement durability. Calcium Aluminates, Balkema, 645-58.

Herisson, J., Guéguen-Minerbe, M., van Hullebusch, E.D., Chaussadent, T. (2017). Influence of the binder on the behaviour of mortars exposed to $\mathrm{H}_{2} \mathrm{~S}$ in sewer networks: a long-term durability study. Materials and Structures, 50(1), 8, DOI: 10.1617/s11527-016-0919-0

Hunsucker, K.Z., Vora, G.J., Hunsucker, J.T., Gardner, H., Leary, D.H., Kim, S., Lin, B., Swain, G. (2018). Biofilm community structure and the associated drag penalties of a groomed fouling release ship hull coating. Biofouling, 34(2), 162-172. DOI: 10.1080/08927014.2017.1417395

Javed, M.A., Stoddart, P.R., Wade, S.A. (2015). Corrosion of carbon steel by sulphate reducing bacteria: initial attachment and the role of ferrous ions. Corrosion Science, 93, 48-57. DOI: 10.1016/j.corsci.2015.01.006

Jia, R., Yang, D., Xu, D., Gu, T. (2017). Electron transfer mediators accelerated the microbiologically influence corrosion against carbon steel by nitrate reducing Pseudomonas aeruginosa biofilm. Bioelectrochemistry, 118, 38-46. DOI: 10.1016/j.bioelechem.2017.06.013

Jia, R., Yang, D., Xu, J., Xu, D., Gu, T. (2017). Microbiologically influenced corrosion of C1018 carbon steel by nitrate reducing Pseudomonas aeruginosa biofilm under organic carbon starvation. Corrosion Science, 127, 1-9. DOI: 10.1016/j.corsci.2017.08.007

Kim, J.S., Kuk, E., Yu, K.N., Kim, J.H, Park, S.J., Lee, H.J., Kim, S.H., Park, Y.K., Park, Y.H., Hwang, C.Y., Kim, Y.K., Lee, Y.S., Jeong, D.H., Cho,M.H. (2007). Antimicrobial effects of silver nanoparticles. Nanomedicine: Nanotechnology, Biology and Medicine, 3(1), 95-101. DOI: 10.1016/j.nano.2006.12.001

Koch, J.H., Brongers, M.P.H., Thompson, N.G., Virmani, Y.P., Payer, J.H. (2002). Corrosion cost and preventive strategies in the United States. Federal Highway Administration, Washington, DC, Report No. FHWA-RD 01-156.

Lee, J.S., Ray, R.I., Little, B.J., Duncan, K.E., Oldham, A.L., Davidova, I.A., Suflita, J.M. (2012). Sulphide production and corrosion in seawaters during exposure to FAME diesel. Biofouling, 28(5), 465-478. DOI: $10.1080 / 08927014.2012 .687723$

Li, L., Li, S., Qu, Q., Zuo, L., He, Y., Zhu, B., Li, C. (2017). Streptococcus sanguis biofilm architecture and its influence on titanium corrosion in enriched artificial saliva. Materials, 10(3), 255. DOI: 10.3390/ ma10030255

Li, Q., Wang, J., Xing, X., Hu, W. (2018). Corrosion behavior of X65 steel in seawater containing sulfate reducing bacteria under aerobic conditions. Bioelectrochemistry, 122, 40-50. DOI: 10.1016/j.bioelechem.2018.03.003

Li, X., Duan, J., Xiao, H., Li, Y., Liu, H., Guan, F., Zhai, X. (2017a). Analysis of bacterial community composition of corroded steel immersed in Sanya and Xiamen Seawaters in China via method of illumina MiSeq Sequencing. Frontiers in Microbiology, 8, 1737. DOI: 10.3389/fmicb.2017.01737

Li, X., Jiang, G., Kappler, U., Bond, P. (2017b). The ecology of acidophilic microorganisms in the corroding concrete sewer environment. Frontiers in Microbiology, 8, 683. DOI: 10.3389/fmicb.2017.00683

Li, Y., Xu, D., Chen, C., Li, X., Jia, R., Zhang, D., Sand, W., Wang, F., Gu, T. (2018). Anaerobic mi- 
crobiologically influenced corrosion mechanisms interpreted using bioenergetics and bioelectrochemistry: A review. Journal of Materials Science \& Technology. [In Press]. DOI: 10.1016/j. jmst.2018.02.023

Liang, R., Aydin, E., Le Borgne, S., Sunner, J., Duncan, K.E., Suflita, J.M. (2017). Anaerobic biodegradation of biofuels and their impact on the corrosion of a $\mathrm{Cu}-\mathrm{Ni}$ alloy in marine environments. Chemosphere, 195, 427-436. DOI: 10.1016/j.chemosphere.2017.12.082

Liu, H., Gu, T., Zhang, G., Wang, W., Dong, S., Cheng, Y., Liu, H. (2016). Corrosion inhibition of carbon steel in CO 2 -containing oilfield produced water in the presence of iron-oxidizing bacteria and inhibitors. Corrosion Science, 105, 149-160. DOI: 10.12783/issn.1544-8053/13/2/10

Long, M., Rack, H.J. (1998). Titanium alloys in total joint replacement - A materials science perspective. Biomaterials, 19(18), 1621-1639. DOI: 10.1016/S0142-9612(97)00146-4

Lv, B., Cui, Y., Tian, W., Feng, D. (2017). Composition and influencing factors of bacterial communities in ballast tank sediments: Implications for ballast water and sediment management. Marine Environmental Research, 132, 14-22. DOI: 10.1016/j.marenvres.2017.10.005

Narenkumar, J., Parthipan, P., Madhavan, J., Murugan, K., Marpu, S.B., Suresh, A.K., Rajaskear, A. (2018). Bioengineered silver nanoparticles as potent anti-corrosive inhibitor for mild steel in cooling towers. Environmental Science and Pollution Research International, 25(6), 5412-5420. DOI: 10.1007/s11356017-0768-6

Narenkumar, J., Parthipan, P., Usha Raja Nanthini, A., Benelli, G., Murugan, K., Rajasekar, A. (2017). Ginger extract as green biocide to control microbial corrosion of mild steel. Three Biotech, 7(2), 133. DOI: $10.1007 / \mathrm{s} 13205-017-0783-9$

Narenkumar, J., Ramesh, N., Rajasekar, A. (2018). Control of corrosive bacterial community by bronopol in industrial water system. Three Biotech, 8(1), 55. DOI: 10.1007/s13205-017-1071-4

Navarro, M., Michiardi, A., Castano, O., Planell, J.A. (2008). Biomaterials in orthopedics. Journal of the Royal Society Interface, 5(27), 1137-1158. DOI: 10.1098/rsif.2008.0151

Punniyakotti, P., Jayaraman, N., Punniyakotti, E., Parameswaran, S.P., Ayyakkannu, U.R.N., Akhil, A., Aruliah, R. (2017). Neem extract as a green inhibitor for microbiologically influenced corrosion of carbon steel API 5LX in a hypersaline environments. Journal of Molecular Liquids, 240, 121-127. DOI: 10.1016/j.molliq.2017.05.059

Raja, P.B., Sethuraman, M.G. (2008). Inhibitive effect of black pepper extract on the sulphuric acid corrosion of mild steel. Materials Letters, 62(17-18), 2977-2979. DOI: 10.1016/j.matlet.2008.01.087

Schultz, M.P., Bendick, J.A., Holm, E.R., Hertel, W.M. (2011). Economic impact of biofouling on a naval surface ship. Biofouling, 27, 87-98. DOI: 10.1080/08927014.2010.542809

Schweitzer, P.A.P.E. (2010). Fundamentals of corrosion - Mechanisms, Causes and Preventative Methods. CRC Press, p. 25.

Sharma, M.A.D., Liu, T., Pinnock, T., Cheng, F., Voordouw, G. (2017). Biocide-mediated corrosion of coiled tubing. Public Library of Science One, 12(7), e0181934. DOI: 10.1371/journal.pone.0181934

Sherar, B.W.A., Power, I.M., Keech, P.G., Mitlin, S., Southam, G., Shoesmith, D.W. (2011). Characterizing the effect of carbon steel exposure in sulfide containing solutions to microbially induced corrosion. Corrosion Science, 53(3), 955-960. DOI: doi.org/10.1016/j.corsci.2010.11.027

Shuler, M.L., Kargi, F. (2002). Bioprocess engineering. New York: Prentice Hall.

Sondi, I., Salopek-Sondi, B. (2004). Silver nanoparticles as antimicrobial agent: a case study on E. coli as a model for Gram-negative bacteria. Journal of Colloid and Interface Science, 275(1), 177-182. DOI: 10.1016/j.jcis.2004.02.012

Souza, J.C.M., Mota, R.R.C., Sordi, M.B., Passoni, B.B., Benfatti, C.A.M., Magin, R.S. (2016). Biofilm formation on different materials used in oral rehabilitation. Brazilian Dental Journal, 27(2), 141-147. DOI: $10.1590 / 0103-6440201600625$ 
Swain, G.W. (2010). The importance of ship hull coatings and maintenance as drivers for environmental sustainability. Proceedings of Ship Design and Operation for Environmental Sustainability, London: Royal Institute of Naval Architects - Ship Design and Operation for Environmental Sustainability Papers, 55-62.

Thauer, R.K., Stackebrandt, E., Hamilton, W.A. (2007). Energy metabolism phylogeneticdiversity of sulphate-reducing bacteria, in: Sulphate-Reducing Bacteria: Environmental and Engineered Systems. Cambridge: Cambridge University Press, 1-27. DOI: 10.1017/CBO9780511541490.002

Videla, H.A. (1986). Corrosion of mild steel induced by sulfate-reducing bacteria. A study of passivity breakdown by biogenic sulphides. Texas: NACE-8 International Corrosion Conference Series, NACE International, Houston, 162-171.

Videla, H.A., Herrera, L.K., Edyvean, R.G.J. (2005). An updated overview of SRB induced corrosion and protection of carbon steel. Corrosion, NACE International, Texas: Houston.

Vincke, E., Wanseele, E. Van, Monteny, J., Beeldens, A., Belie, N., De, Taerwe, L., Gemert, D. Van, Verstraete, W. (2002). Influence of polymer addition on biogenic sulfuric acid attack of concrete. International Biodeterioration \& Biodegradation, 49(4), 283-292. DOI: 10.1016/S0964-8305(02)00055-0

Wan, H., Song, D., Zhang, D., Du, C., Xu, D., Liu, Z., Ding, D., Li, X. (2018). Corrosion effect of Bacillus cereus on X80 pipeline steel in a Beijing soil environment. Bioelectrochemistry, 121, 18-26. DOI: 10.1016/j.bioelechem.2017.12.011

Wang, H., Ju, L.K., Castaneda, H., Cheng, G., Newby, B.M.Z. (2014). Corrosion of carbon steel C1010 in the presence of iron oxidizing bacteria Acidithiobacillus ferrooxidans. Corrosion Science, 89, 250-257. DOI: $10.1016 /$ j.corsci.2014.09.005

World Health Organisation (2000). Hydrogen Sulfide, in: Air Quality Guidelines for Europe. Copenhagen, p. 7.

Xu, D., Gu, T. (2011). Bioenergetics Explains When and Why More Severe MIC Pitting by SRB Can Occur. Corrosion/2011, NACE International, Texas: Houston.

$\mathrm{Xu}, \mathrm{D}$., Li, Y., Gu, T. (2016). Mechanistic modeling of biocorrosion caused by biofilms of sulfate reducing bacteria and acid producing bacteria. Bioelectrochemistry, 110, 52-58. DOI: 10.1016/j.bioelechem.2016.03.003

Xu, D., Li, Y., Song, F., Gu, T. (2013). Laboratory investigation of microbiologically influenced corrosion of C1018 carbon steel by nitrate reducing bacterium Bacillus licheniformis. Corrosion Science, 77, 385-390. DOI: 10.1016/j.corsci.2013.07.044

Yuan, L., Gao, T., He, H., Jiang, F.L., Liu, Y. (2017). Silver ion-induced mitochondrial dysfunction via a nonspecific pathway. Toxicology Research, 6(5), 621-630. DOI: 10.1039/C7TX00079K

Zhang, P., Xu, D., Li, Y., Yang, K., Gu, T. (2015). Electron mediators accelerate the microbiologically influenced corrosion of 304 stainless steel by the Desulfovibrio vulgaris biofilm. Bioelectrochemistry, 101, 14-21. DOI: 10.1016/j.bioelechem.2014.06.010

\section{Krótki przegląd badań nad biokorozją}

Streszczenie

Korozja to ogół procesów prowadzących do niszczenia materiałów. Jednym z typów korozji jest korozja powodowana działaniem mikroorganizmów. Tak zwana Biokorozja w znacznym stopniu przyczynia się do degradacji konstrukcji metalowych i betonowych. Niektóre elementy tych konstrukcji, w szczególności te wystawione na działanie wody słodkiej, słonej, ścieków albo ziemi są szczególnie narażone na destrukcyjny wpływ mikrobów. Korozja mikrobiologiczna w największym stopniu dotyka przemysłu naftowo-gazowego, transportu wodnego i instalacji sanitarnych. Niebagatelny problem stanowi także, powodowana przez bakterie znajdujące się w jamie ustnej, korozja implantów dentystycznych. Mimo, że mechanizmy 
powodujące biokorozję nie są dobrze znane, walka z tym zjawiskiem jest przedmiotem badań instytutów na całym świecie. Ważnym zagadnieniem jest również projektowanie materiałów o zwiększonej odporności na biokorozję. Celem tego artykułu jest podsumowanie dotychczasowego stanu wiedzy o zjawisku biokorozji, przybliżenie obecnie stosowanych metod jej zapobiegania, oraz omówienie procesów chemicznych i biologicznych stojących za korozją indukowaną przez mikroorganizmy.

Key words: bacteria, biofilm, inhibitors, mechanism, microbial induced corrosion

Received: [2018.07.10]

Accepted: [2018.09.25] 